УДК 159.9

(C) I.B. Лантух, 2019

orcid.org/0000-0002-0891-2704

http://doi.org/10.5281/zenodo.2560052

\title{
ЛАНТУХ Ігор Валерійович
}

кандидат економічних наук, доцент кафедри гігієни та соиіальної медицини

Харківського начіонального університету

імені В. Н. Каразіна

\section{ТЕОРЕТИЧНІ ПІДХОДИ ДО ОБГРУНТУВАННЯ ПСИХОЛОГІЧНОЇ СТРУКТУРИ ОСОБИСТІСНОЇ НАДІЙНОСТІ СУБ'ЄКТІВ ПІДПРИЕМНИЦЬКОї ДІЯЛЬНОСТІ}

У статті розглядаються питання теоретико-методологічного обтрунтування дослідження психологічної структури особистісної надійності суб'єктів підприємницької діяльності. Описано ряд теоретичних особливостей дослідження надійності підприємців. Наведені та описані кониептуальні підходи, які поглиблюють поняття особистісної надійності та розширюють знання про психологічну структуру суб'єктів підприємницької діяльності. Розвиток $i$ формування особистісної надійності підприємщів $у$ професійній діяльності повинні розглядатись у наступних напрямках діяльність, надійність та спільність. Так, професійна діяльність підприємиів - інтерсуб 'єктивна; професійна надійність грунтується на позитивному самовизначенні у взаємодії, а професійна спільність обумовлена включенням підприємців у колективну діяльність.

Ключові слова: суб’єкт підприємницької діяльності, психологічна структура, особистісна надійність, концептуальні підходи, професіоналізм підприємия.

Постановка проблеми. Сучасний стан України потребує професіоналів, які активно вносять свій вклад у розвиток економіки суспільства. Провідну роль в цьому аспекті відіграють фахівці підприємницької діяльності, які можуть впроваджувати у практику сучасної економіки нові наукові дослідження через свій професіоналізм та особистісну надійність. У значних наукових напрацюваннях учених звернуто увагу на те, що аспектом пильного розгляду сьогодні $\epsilon$ психологічні особливості структури особистісної надійності та професіоналізму підприємців і їхня роль в продуктивній професійній діяльності на благо України. 
Аналіз останніх досліджень і публікацій. Проблемі розвитку професіоналізму фахівців та формуванні їхньої особистісної надійності присвячені роботи вчених: Г. Балл (2008), $\quad$ А. М. Бандурки, О. В. Землянської (1998), В. І. Барко (2007), Е. Ф. Зеєра (2000), Л. М. Карамушки (2011), Р. 3. Кісіль (2007), С. Ю. Клімова (2005), В. А. Криволапчука (2013), В. О. Лєфтерова (2008). Професійна надійність підприємців розглядається як інтегральна якість особистості, яка може впливати на професійну активність фахівця незалежно від складних умов праці. Надійність підприємця проявляється у професійній діяльності і формує стійкий стан об'єктивної та суб'єктивної здатності до співпраці та підвищення іiї ефективності. Дослідник В. А. Криволапчук (2013) у структурі психологічної надійності виділяє наступні компоненти: мотиваційні, когнітивні, емоційно-вольові, поведінкові, які впливають на розвиток та реалізацію професійної надійності підприємців. Автор звертає увагу на те, що особистісна надійність лежить в основі формування здібностей ефективно виконувати професійну діяльність у складних умовах трудового процесу.

На думку 3. Р. Кісіль (2007), накопичений сучасною теорією i практикою психологічної науки теоретичні й емпіричні дослідження можуть слугувати відправною точкою для використання інтегрального підходу до розробки професіоналізму фахівців підприємницької діяльності. Важливе значення автор приділяє проблемі самоконтролю, самореалізації i надійності підприємців у професійній діяльності.

У системі особливостей професійної діяльності фахівців Є. О. Клімов (2005) висвітлює проблеми самовизначення, самовідношення та їх адаптаційних можливостей. Дослідник В. О. Толочек (1998) вивчає проблеми ризику і стилю професійної діяльності фахівців та їх професійне довголіття.

Мета статті - показати основні теоретичні підходи до обгрунтування психологічної структури особистісної надійності суб'єктів підприємницької діяльності.

Виклад основного матеріалу дослідження. Успішне виконання професійної діяльності підприємцями пов'язане 3 внутрішнім і зовнішнім професійним потенціалом особистості, який допомагає суб'єктам підприємницької діяльності 
реалізувати себе в складних, нестандартних умовах та екстремальних ситуаціях. Накопичений внутрішній потенціал підприємець використовує для отримання успішного результату в професійній діяльності. Сучасні теоретичні розробки дають можливість виявити головні напрями дослідження проблеми надійності суб'єктів підприємницької діяльності. Значним внеском $\epsilon$ роботи науковців, які приділяють увагу розробці концептуальних підходів до вивчення психології надійності та професіоналізму суб'єктів підприємницької діяльності. Як зазначає 3. Р. Кісіль (2007), теоретичну основу психологічних концепцій дослідження фахівців у професійній діяльності складають наступні підходи: концеепиія діяльності як цілеспрямованої відкритої системи і людини - суб'єкта діяльності, що реалізує й розвиває свій професійний потенціал; кониепиія інформаційних і концептуальних підходів; трансформаційна теорія навчання та конщепція впливу екстремальних умов; конщепція забезпечення професійної надійності людини; концепиії вимог до властивостей людинипрофесіонала, професійного відбору, тренажерної підготовки й спеціальної реабілітації людей після напруженої і небезпечної професійної діяльності; конщепщія збереження здоров'я й професійного довголіття; кониееиія проектування діяльності. На думку автора, ці виділені теоретичні підходи вивчення психології надійності підприємців у професійній діяльності, дозволяють через арсенал концепцій, категорій, методик та методів отримати широкий спектр результатів досліджень. Він висловлює думку, що провідними методологічними принципами дослідження надійності можуть бути: техніко-економічна, природничо-наукова, культурно-історична парадигми, що дозволяє поєднувати гуманістичні цінності з якісно-професійними моделями фахової діяльності особистості. В цих дослідженнях системно утворюючим принципом $\epsilon$ професійна спрямованість і особистісна надійність, які $€$ основою формування професійної успішності та розвивають особистий потенціал підприємців.

Цілісне розкриття феномену психологічної надійності суб'єктів підприємницької діяльності науковці розкривають 3 урахуванням, як позитивних, так і негативних якостей, що впливають на особистість професіонала. Важливе значення у 
підвищенні працездатності підприємців має мотивація на успіх у виконанні професійної діяльності. На розвиток надійності підприємця активно впливає його «Я-концепція», яка розглядається як система уявлень фахівця про себе, своє відношення до успіху та невдач у професійній діяльності. Розвиток «Я-концепції» професіонала пов'язаний 3 формуванням соціально-психологічного самопочуття підприємця, як емоційно-ціннісного ставлення до себе, до діяльності і це $\epsilon$ інтегральною характеристикою збалансованості і гармонійності внутрішнього світу суб'єктів підприємницької діяльності (Котик, 2009).

М. А. Ажажа (2010) описує основні положення вивчення шляхів корекції особистісних якостей менеджера-професіонала $\mathrm{i}$ презентує їх у наступних теоріях: 1) теорія рис - обгрунтовує особистісні якості, які необхідні фахівцю для успішної професійної діяльності; 2) факторний підхід - передбачає аналіз окремих чинників, які впливають на розвиток професійної надійності різних досліджуваних груп; 3) ситуаиійна теорія стверджує, що лідерство є продуктом ситуації групового життя, в яких виокремлюють осіб, що мають перевагу над іншими i керують ними у професійній діяльності. Це формує у лідера стійкий стан, котрий забезпечує об'єктивну i суб'єктивну здатність до співпраці і ефективної діяльності; 4) париіальна концепиія - передбачає дослідження і корекцію особистісних способів та методів орієнтації підприємців у соціальному середовищі, націленому на зміну поведінки та самооцінки; 5) системний niдxiд - полягає у вивчені досліджуваного феномена як цілісної системи, в якій сукупність окремих компонентів у взаємодії дає змогу виявити нові якості особистості, що забезпечують ефективне функціонування всієї системи; 6) поведінковий підхід - вважає, що підприємець володіє формами поведінки, необхідними в соціумі та для групи, якою він керує.

Таким чином, сучасні дослідження особистісної надійності підприємців 3 позиції різних теорій, концепцій та підходів доповнюють систему знань про іiі психологічні особливості, що дозволяє впливати на іiі розвиток у підприємця 3 метою його ефективної професійної діяльності. Наукові пошуки молодої незалежної України в умовах демократизації суспільства 
потребують враховувати зміни в особистості у нових умовах буття та професійної діяльності. Сучасний підприємець повинен не тільки адаптуватись до нової суспільної реальності в Україні, але й бути активним, ініціативним та ефективним у своїй професійній діяльності. Теоретичний та практичний досвід науки служить основою для розробки інтегрального підходу до вивчення особистісної надійності суб'єктів підприємницької діяльності (Кононець, 2013).

О. В. Кобець (2015), вивчаючи професійну діяльність фахівців, приділив увагу принципу професіоналізму, який, на його думку, передбачає комплексне вивчення професіонала, його властивостей, професійного стану у фаховій діяльності. Розглядаючи проблему професіоналізму фахівців, він стверджує, що його стан як професіонала може бути внутрішньо і зовнішньо схарактеризованим. Характеристика професіоналізму як системи описується автором на основі функціонального, морфологічного та емоційного підходів. Професіоналізм як об'єкт вивчення притягує інтерес до того, яке місце він займає серед інших психологічних явищ суб'єкта фахової діяльності. Враховуючи ці підходи, професіоналізм фахівця треба вивчати, починаючи 3 опису його функцій i критеріїв. Розглядаючи професійні функції фахівців, варто звернути увагу на те, що ці функції вивчаються 3 урахуванням обов'язків, які виконує фахівець у професійній діяльності, а також кола тих завдань, які необхідно йому вирішувати. Розроблені автором критерії професіоналізму дозволяють мати уявлення про сутність виконання узагальнених i конкретних функцій об'єкта, що вивчається, з процесуального напряму. Функції професіоналізму спрямовані на якісне перетворення суб'єкта діяльності i орієнтовані на ефективне виконання професійних завдань, а саме: створення таких професійних умов, за яких продуктивність i якість праці будуть становити не нижче нормативного рівня; збереження нормативно схваленого способу конкретного професійного напряму на основі індивідуальних якостей; розвиток надійності професіоналів та спільноти, що $\epsilon$ частиною професійного співтовариства, учасником якого $є$ фахівець.

У загальному випадку виконання професійних функцій підприємцем супроводжується отриманням не тільки 
нормативних результатів підприємницької діяльності, але й певних витрат, які можуть бути як матеріально-економічними, так і соціально-психологічними. Такі підходи потребують вивчення умов розвитку психологічної надійності суб'єктів підприємницької діяльності для підвищення їхнього професіоналізму та ефективності праці (Криволапчук, 2013).

Інтенсивність психологічного аналізу феномену надійності у конкретній галузі соціального буття, надає можливості внести своєчасні корективи та покращити етико-емоційний стан у суспільстві. Такі дослідження дають поглиблений аналіз суті та значущості надійності як феномена взаємодії та довіри в суспільстві (Василець, 2012). Дослідження надійності сприяє систематизації знання про розуміння надійності та іiі значущості У національному й культурному просторі України. 3 огляду різних теоретичних досліджень та методологічних практик утвердилась думка про те, що надійність є ключовою категорією для конструювання моделей суспільного життя, що потребує іiі присутності в людських взаєминах, як на благо особистості, так і на благо розвитку українського суспільства (Карамушка, 2011).

Аналіз рефлексії надійності суб'єктів підприємницької діяльності у соціокультурному дискурсі України показав інтерес науковців до цієї проблеми і спробу ввести іï в національний науковий дискурс. Науковий аналіз надійності дає змогу залучати цей феномен до раціонального дискурсу ціннісних трансформацій українського суспільства. Особистісна надійність стала предметом наукової дискусії, що дозволило корелювати iі з такими практиками, як економіка, соціологія, державне управління, психологія у наступному сенсі: причини іiі кризи; потреби іiі обгрунтування у відповідному українському соціумі; прогнозування механізмів підвищення рівня надійності суб'єктів економічної діяльності у суспільстві (Панчук, 2017).

До переліку найбільш значущих проблем підприємців потрапили такі як: неефективність психолого-економічної взаємодіі; неефективність організачійно-управлінських засобів; иіннісно-інституиійна деградація важливих сегментів фінансового ринку; причини глобальної економічної кризи; зміни логіки функиіонування взаємин у боротьбі 3 корупцією (Шадриков, 1982). 
Потреба у вирішенні актуальних питань надійності суб'єктів підприємницької діяльності стає умовою оздоровлення економіки і їі здатність консолідувати суспільство у розв'язанні проблем його розвитку. У підприємницькій діяльності в економіці надійність розглядається як компонент ціннісної основи раціонального вибору діяльності, прийняття рішень в умовах суперечливої інформації, оптимізації результатів господарювання. Надійність в підприємницькій діяльності зменшує трансактивні витрати за умов налагодження відносин контрольно-перевірочної діяльності партнерів і самоконтролю (Малеев, 2016).

Таким чином, особистісна надійність формує відчуття взаємної довіри, що створюю ситуацію ефективних взаємин у підприємницькій діяльності. Подолання соціально-економічних негараздів в українському суспільстві не може відбутися без високорозвиненої надійності фахівців господарської діяльності. Відродження надійності у підприємців, у суспільстві, взагалі, є запорукою поглиблення демократизації співпраці як норми буття, що позитивно впливає на рівень ділової активності, успішної професійної діяльності, підвищення емоційного самопочуття, що покращує виробництво та його обсяг. Особливий акцент у сучасних дослідженнях надійності наголошується на тому, що вона сприяє соціальній інтеграції та підтримує інновації в економічному розвитку країни. В той же час, механізмом збереження надійності вважається відкритий, толерантний, чесний діалог у комунікативній системі суб'єктів підприємницької діяльності. На думку дослідників, надійність фахівців відіграє провідну роль у мінімізації рівня корупції в суспільстві і створює умови для прозорості, відкритості, чесної конкурентоспроможності в розбудові економіки (Кононець, 2013; Митина, 2008).

Із вищевикладеного для нашої роботи ми виділяємо наступні теоретико-методологічні принципи та концепції.

1. Принциип професійного розвитку особистості. Потребує вирішення зовнішніх і внутрішніх протиріч суб'єктів підприємницької діяльності. Ці протиріччя можуть виникати між інтересами і спрямованістю фахівців та їх професійними можливостями. Професійне становлення фахівця потребує збагачення його внутрішніх ресурсів, що пов'язано 3 
перетворенням особистісних якостей, його індивідуального потенціалу. У фаховій діяльності підприємців відбуваються різні моделі професійної свідомості, що допомагає вирішувати складні професійні завдання. На цій основі розвиток професійної надійності спонукає до підвищення ефективності праці.

2. Принциип організаціï. Показує, що особистість організує свій досвід і свої якості, які мають індивідуальні відмінності та утворюють систему, відмінну від інших суб'єктів діяльності, i функціонують в цій системі, долаючи життєві труднощі. Особистісна надійність розширює індивідуальні можливості підприємців в організації професійної діяльності.

3. Приници вибору. Показує, що особистість розвивається в напрямі, корисному для себе або для соціуму. Для особистості використання одних якостей може бути пріоритетними над іншими, що дає змогу ефективно розвивати свій бізнес. Так як професійні стосунки в підприємницькій діяльності не є постійними, то це обумовлює організаційні зміни 3 формуванням нової системи взаємодії.

4. Принциип індивідуальності. Показує, що кожна людина створює коло своєї професійної діяльності на основі унікальної системи особистісних якостей, що відкриває можливості для активної діяльності в підприємницькій сфері. Проявляючи надійність, кожний підприємець підвищує індивідуальний авторитет серед своїх колег-фахівців.

5. Принции спільності. Показує, що підприємці мають широке коло взаємодії, але спілкуються більше $з$ тими, до яких $є$ професійний або особистісний інтерес та які мають надійний досвід, або одну культуру взаємодії.

6. Принцип співдружності. Показує, що для продуктивної взаємодії в підприємницькій діяльності необхідно, щоб партнери правильно інтерпретували взаємні дії, що призведуть до успіху. Успішна соціальна взаємодія дає позитивний ефект, коли партнери мають взаємне розуміння та погляди на життя, соціальні прогнози і підтримуються іншими.

7. Принщип конкуренціï. Показує, що в професійній діяльності у підприємців є бажання зайняти краще соціальне середовище для збільшення прибутку або кращого вирішення фахових питань. Зіткнення різних точок зору суб'єктів і груп в 
мікро- і макросередовищі посилює конкуренцію і потребує від підприємців вміння не тільки вистояти, а й підвищити свою конкурентоздатність. На міжособистісному, міжгруповому i мікросоціальному рівнях можуть відбуватися як негативні, так i позитивні наслідки конкуренції. Найбільш успішні й конкурентностійкі ті фахівці, які мають високорозвинену професійну надійність.

8. Принциип балансу цінностей. Означає визнання у суб'єктів різних підходів, гіпотез, протилежних стратегій, особистісних та суспільних цінностей, які пропонуються партнерами або різними групами взаємодії. Такий стан може як розвивати, так i негативно впливати на розвиток підприємницької діяльності, знижувати успіхи та змінювати цінності міжособистісної та соціальної взаємодії. Високорозвинена професійна надійність допомагає підприємцям збалансовувати цінності взаємодії в професійній діяльності.

9. Принции пульсащіï. Показує, що особистісна система суб'єктів підприємницької діяльності має не тільки постійний розвиток цієї системи, але й періодичних ціннісних іiі змін. Це обумовлює проявлення особистістю різних своїх станів, як глибинних, так і поверхневих, і створює умови приписування певних рис партнерам по взаємодії, підтримку звичних смислових стратегій, зняття суперечностей. Усе це вимагає активно розвивати особистість підприємця й підвищувати його надійність.

10. Принции діапазону. Звертає увагу на те, що підприємці, які мають набір об'єктивних та суб'єктивних якостей плідно працюють і взаємодіють з такими партнерами, які найбільш надійні. Це дозволяє суб'єкту підприємницької діяльності успішно працювати, розширювати діапазон взаємодії і мати підтримку партнерів.

11.Інформаційний принциип. Дозволяе виявити динаміку розвитку підприємства, вибрати найбільш надійних та успішних підприємців, як партнерів, і мати інформацію про загальний стан розвитку підприємницької діяльності в регіоні та суспільстві. Прогнозування надійності виконання професійних завдань вимагає виділяти основні принципи іiі побудови. Такий підхід прогнозування надійності для успішної діяльності 
фахівців дозволяє передбачити тенденції iї розвитку і хід процесів у професійній діяльності.

Аналіз існуючих підходів, щодо складання прогнозів, дозволив виділити наступні їхні види: 1) основні типи: нормативні (визначення напрямів $\mathrm{i}$ термінів досягнення); пошукові (можливих станів, явищ у майбутньому); 2) періоди попередження: оперативні; короткострокові; середньострокові; довгострокові; недовго строкові. Прогнозування успішної професійної діяльності підприємців $є$ найбільш актуальними та довгостроковими прогнозами. Дослідники виділяють наступні параметри прогнозу: термін попередження або глибина прогнозу; період прогнозу, що будує ретроспекцію; прогнозний горизонт - це період встановлення точності прогнозу; точність прогнозу - визначається оцінкою довільного інтервалу прогнозу; вірогідність прогнозу - це прогноз в заданому інтервалі; надійність прогнозу - стійкість, статичність прогнозованого явища (Малеев, 2016).

При розробці прогнозу надійності професійної діяльності підприємців необхідно отримати інформацію про особливості психологічного складу фахівців через бесіди, спостереження, експертні оцінки. Отримана оцінка часто має описовий характер про особистість, іï кваліфікацію, іiі поведінку. На практиці використання психологічних методик, дозволило активно досліджувати надійність фахівців. Високий рівень сформованості інтелектуальної діяльності фахівця складається із стійкості таких психологічних характеристик як: повнота та точність інформації, готовність до іiі оперативного використання. Незважаючи на велику кількість спеціальної інформації, відмічається ускладнення процедури прогнозування професійної надійності особистості, що вимагає всебічного об'єктивного вивчення професійно важливих якостей підприємців (Шадриков, 1982).

У ролі важливого компонента професійної надійності виступає емоційно-вольова стійкість, як здатність виконувати професійні завдання в умовах емоційного впливу, шляхом співставлення результатів діяльності. Принципово важливим $\epsilon$ положення використання психічних моделей емоційних ситуацій, в основу яких покладені специфічні емоційні чинники, характерні для діяльності підприємців. Важливість прогностики 
в діяльності підприємців є очевидною, бо складання прогнозів надійності допомагає покращити професійну діяльність фахівців (Панчук, 2017).

Таким чином, надійність суб'єктів підприємницької діяльності активізує розвиток як професіоналізму, так i особистісних їх якостей. Відповідно до цього підприємець одночасно є суб'єктом у підприємницькому середовищу і в колективній взаємодії. Як член підприємницького колективу він виступає проектувальником, конструктором, організатором i безпосереднім учасником відносин у взаємодії, а також носієм певної особистісної позиції, що припускає необхідність прояву фахівцем професійної надійності. Як суб'єкт підприємницької діяльності, підприємець повинен володіти відповідними етичними нормами, способами і засобами реалізації професійної надійності. На підставі зазначеного інтерес до структури професійної надійності суб'єктів підприємницької діяльності цілком виправданий та своєчасний.

Висновки та перспективи подальших розвідок. Розвиток i формування особистісної надійності підприємців у професійній діяльності повинна розглядатись у наступних напрямках - діяльність, надійність та спільність. Так, професійна діяльність підприємців - інтерсуб'єктивна; професійна надійність грунтується на позитивному самовизначенні у взаємодії, а професійна спільність обумовлена включенням підприємців у колективну діяльність, що грунтується на позитивному самовизначенні 3 учасниками взаємодії. Відповідно до цього, слід звернути увагу на те, що суб'єкт підприємницької діяльності виступає одночасно організатором, проектувальником, носієм особистісної позиції, що припускає самовизначення, самоорганізацію, самосвідому професійну діяльність.

Суб'єкт підприємницької діяльності розглядається науковцями в системній сукупності, його здатності до саморозвитку, самовдосконалення, розширення якісних характеристик своєї особистості як професіонала. В цьому аспекті важливе значення має єдність індивідуальнотипологічних, інтелектуальних та професійних якостей фахівців. Дослідження поняття професійного потенціалу особистості вивчається у взаємозв'язку компонентно-структурного аналізу, 
який дає змогу розглядати професійний потенціал фахівця в генетично-прагматичному аспекті та як біосоціальну систему, що дозволяє ефективно розвивати природні якості фахівця.

Перспективою подальшого дослідження є поєднання відносно однорідних складових особистості фахівця 3 більш широкою системою професійних якостей підприємця. 3 цих позицій структурний аналіз професійного потенціалу підприємців дає змогу вивчати не тільки особистісні якості, а й вплив соціального середовища, що поєднує внутрішні та зовнішні характеристики фахівця у його професійному розвитку.

\section{Список використаних джерел}

Ажажа М.А. Соціально-психологічний портрет майбутнього менеджера соціальної служби / М.А. Ажажа // Гуманітарний вісник Запорізької державної інженерної академї. - 2010. Вип. 42. - С. 236-246.

Балл Г. Орієнтири сучасного гуманізму (в суспільній, освітній, психологічній сферах): монографія / Г.О. Балл. - Житомир : Рута, Видавництво «Волинь», 2008. - 232 с.

Бандурка А.М. (1998) Психология управления / А.М. Бандурка, С.П. Бочарова, Е.В. Землянская. - Харьков : ООО «Фортунапресс», 1998. - 464 с.

Барко B.I. Професіографічний опис основних видів діяльності в органах внутрішніх справ України: монографія / В.I. Барко. К. : РВЦ КНУВС : Друкарня МВС, 2007. - 100 с.

Василець Н.М. Довіра як підгрунтя толерантності у психологопедагогічний взаємодії / Н.М. Василець // Науковий вісник Львівського держ. ун-ту внутрішніх справ. Серія психологія. 2012. - №1. - С.114-121.

Зеер Э.Ф. Психология личностно-ориентированного профессионального образования / Э.Ф. Зеер. - Екатеринбург : Изд-во Урал. гос. проф.-пед. ун-та, 2000. - 244 с.

Карамушка Л.М. Мотивація підприємницької діяльності: монографія / Л.М. Карамушка, Н.Ю. Худякова. - Львів : Сполом, 2011. $208 \mathrm{c}$.

Кісіль 3.Р. Психологічна надійність професіонала як фактор протидії деформації. / 3.Р. Кісіль // Університетські наукові записки. 2007. - № 4(24). - С.80-88.

Климов Е.А. Психология профессионала: Избранные психологические труды / Е.А. Климов. - М. : МПСИ, 2003. - 456 с.

Кобець О.В. Еталони правосвідомості як психологічний механізм саморегуляції соціальної оцінки особистості професіонала / О.В. Кобець // Вісник ХНПУ ім. Г.С. Сковороди. Психологія. $-2005 .-$ Вип. 15. Ч. II. - С.125-135. 
Кононець М.О. Психологія професійної моральності підприємців: теорія та сучасна практика: монографія / М.О. Кононець. - К. : Омега-Л, 2013. - 166 с.

Котик I. Соціокультурні кореляти особистісної надійності / І. Котик // Актуальні проблеми економічного розвитку України в умовах глобалізації. 3б. наук. праць Міжнародної наукової практичної конференції. Ч.І. Вінниця : Центр підготовки навчальнометодичних видань ВТЕІ КНТЕУ, 2009. - С.132-136.

Криволапчук В.А. Концептуальные подходы к разработке программы формирования профессиональной психологической надёжности сотрудников криминальной милиции МВД Украины / В.А. Криволапчук // Психопедагогика в правоохранительных органах. - 2013. - № 3 (54). - С.63-64.

Лєфтеров В.О. Психологічні тренінгові технології в органах внутрішніх справ: монографія. У 2-х т. / В.О. Лєфтеров. Донецьк : ДКМ, 2008.

Малеев Д.В. Психологічні чинники розвитку професійної надійності працівників підрозділів превентивної діяльності національної поліції України: автореф. дис. ... канд. психол. наук: 19.00.06; МВС України, Харк. нац.. ун-т внутр. справ. / Д.В. Малев. Харків, 2016. - 22 с.

Митина Л.М. Психология конкурентоспособной личности: монографія / Л.М. Митина. - М. : НПО Модэк, 2008. - 464 с.

Панчук М.Т. Ціннісні орієнтації як системоутворюючий фактор соціально активної позиції майбутнього фахівця / М.Т. Панчук // Проблеми сучасної психології. - 2017. - Вип. 21. - С.105115.

Толочек В.А. Стили профессиональной деятельности в условиях взаимодействия субъектов: автореф. дис. ... доктор. психол. наук / В.А. Толочек. - М., 1998. - 48 с.

Шадриков В.Д. Проблемы системогенеза профессиональной деятельности: монографія / В.Д. Шадриков. - М. : Наука, 1982. $-185 \mathrm{c}$.

\section{References}

Azhazha M.A. (2010) Socialno-psihologichnij portret majbutnogo menedzhera socialnoyi sluzhbi [Socio-psychological portrait of the future manager of social service].[Gumanitarnij visnik] [HPA: Humanitarian Herald], 42, 236-246 [in Ukrainian].

Ball G. (2008) Oriyentiri suchasnogo gumanizmu (v suspilnij, osvitnij, psihologichnij sferah: monograflya) [Landmarks of modern humanism (in the social, educational, psychological areas] Zhitomir: Ruta; Volin [in Ukrainian].

Bandurka A.M. (1998) Psihologiya upravleniya: monograflya [Psychology of Management: Monograph] Kharkiv.: Un-t vnut. Del [in Russian].

Barko V.I. (2007). Profesiografichniy opis osnovnih vidiv diyalnosti v organah vnutrishnih sprav Ukrayini: monografiya. [Professional 
description of the main types of activity in the internal affairs bodies of Ukraine: monograph.] Kiyiv [in Ukrainian].

Vasilets N.M. (2012). Dovira yak pidgruntya tolerantnosti u psihologopedagogIchniy vzaemodiyi. [Trust as the basis of tolerance in psychological and pedagogical interaction] Lviv [in Ukrainian].

Zeer E.F. (2000). Psihologiya lichnostno-orientirovannogo professionalnogo obrazovaniya [Psychology of personal-oriented vocational education]. Ekaterinburg: Ural [in Russian].

Karamushka L.M. (2011). Motivatsiya pidpriemnitskoyi diyalnosti: monografiya. [Motivation for entrepreneurship: monograph.] Lviv: Spolom [in Ukrainian].

Kisil Z.R. (2007). Psihologichna nadiynist profesionala yak faktor protidiyi deformatsiyi.[Psychological reliability of a professional as a factor of deformation resistance] Universitetski naukovi zapiski [in Ukrainian].

Klimov E.A. (2003). Psihologiya professionala: izbrannyie psihologicheskie trudyi. [Professional Psychology: Selected Psychological Works] Moscow [in Russian].

Kobets O.V. (2005). Etaloni pravosvidomosti yak psihologIchniy mehanizm samoregulyatsiyi sotsialnoyi otsinki osobistosti profesionala [Standards of legal consciousness as a psychological mechanism of self-regulation of social assessment of a professional's personality.] Harkiv: HNPU [in Ukrainian].

Kononets M.O. (2013). Psihologiya profesiynoyi moralnosti pidpriemtsiv: teoriya ta suchasna praktika: monografiya. [Psychology of Professional Morality of Entrepreneurs: Theory and Modern Practice: Monograph.] Kyiv : Omega-L [in Ukrainian].

Kotik I. (2009). Sotsiokulturni korelyati osobistisnoyi nadiynosti. Aktualni problemi ekonomichnogo rozvitku Ukrayini v umovah globalizatsiyi. [Socio-cultural correlations of personal reliability. Actual problems of economic development of Ukraine in the conditions of globalization.] Vinnitsya: VTEI KNTEU [in Ukrainian].

Krivolapchuk V.A. (2013). Kontseptualnyie podhodyi k razrabotke programmyi formirovaniya professionalnoy psihologicheskoy nadyozhnosti sotrudnikov kriminalnoy militsii MVD Ukrainyi.[Conceptual approaches to the development of a program for the formation of professional psychological reliability of employees of the criminal militia of the Ministry of Internal Affairs of Ukraine.] Psihopedagogika $\mathrm{v}$ pravoohranitelnyih organah [in Ukrainian].

Lefterov V.O. (2008). Psihologichni treningovi tehnologiyi $\mathrm{v}$ organah vnutrishnih sprav: monografiya. [Psychological training technologies in internal affairs bodies: monograph] Donetsk: DKM [in Ukrainian].

Maleev D.V. (2016). Psihologichni chinniki rozvitku profesiynoyi nadiynosti pratsivnikiv pidrozdiliv preventivnoyi diyalnosti natsionalnoyi politsiyi Ukrayini: avtoref. dis.[ Psychological 
factors of development of professional reliability of employees of units of preventive activity of the National Police of Ukraine: author's abstract. dis] Harkiv [in Ukrainian].

Mitina L.M. (2008). Psihologiya konkurentosposobnoy lichnosti: monografiya.[ Psychology of Competitive Personality: Monograph.] Moscow [in Russian].

Panchuk M.T. (2017). Tsinnisni orientatsiyi yak sistemoutvoryuyuchiy faktor sotsialno aktivnoyi pozitsiyi maybutnogo fahivtsya. [Valuable orientations as a system-forming factor of a socially active position of a future specialist.] Problemi suchasnoyi psihologiyi [in Ukrainian].

Tolochek V.A. (1998). Stili professionalnoy deyatelnosti v usloviyah vzaimodeystviya sub'ektov: avtoref. dis.[ Styles of professional activity in the conditions of interaction of subjects: author's abstract. dis] Moscow [in Russian].

Shadrikov V.D. (1982). Problemyi sistemogeneza professionalnoy deyatelnosti: monograflya. [Problems of systematization of professional activity: monograph.] Moscow: Nauka [in Russian].

\section{Lantukh}

\section{THEORETICAL APPROACHES TO THE SUBMISSION OF PSYCHOLOGICAL STRUCTURE OF PERSONAL RELIABILITY OF SUBJECTS OF BUSINESS ACTIVITIES}

The article deals with the issues of theoretical and methodological substantiation of the study of the psychological structure of personal reliability of business entities. A series of theoretical peculiarities of reliability research of entrepreneurs is described. Conceptual approaches that deepen the concept of personal reliability and expand knowledge about the psychological structure of business entities are presented and described. Development and formation of personal reliability of entrepreneurs in professional activity should be considered in the following directions - activity, reliability and community. So, professional activity of entrepreneurs is inter-subjective: professional reliability is based on positive self-determination in interaction, and professional community is due to the inclusion of entrepreneurs in collective activities, which is based on positive selfidentification with the participants of the interaction. Accordingly, one should pay attention to the fact that the subject of entrepreneurial activity acts simultaneously as an organizer, designer, carrier of a personal position, which involves selfdetermination, self-organization, self-conscious professional activity. The prospect of further research is a combination of relatively homogeneous components of the personality of a specialist with a wider system of professional qualities of an entrepreneur. From these positions, the structural analysis of the entrepreneurial professional potential enables one to study not only personal qualities, but also the influence of the social environment, which combines the internal and external characteristics of the specialist in his professional development.

Key words: subject of entrepreneurial activity, psychological structure, personal reliability, conceptual approaches, professionalism of the entrepreneur.

Надійшла до редакції 31.12.2018 p. 